\title{
1989 - Året som endret Europa
}

\author{
Per Anders Madsen \\ Oslo: Gyldendal Norsk Forlag 2019 \\ 367 sidor. ISBN 9788205519787
}

Recenserad av Thomas Lundén [professor emeritus i kulturgeografi, Centrum för Östersjö- och Östeuropaforskning (CBEES), Södertörns högskola, thomas.lunden @sh.se]

1989 har betecknats som slutet på det korta 1900-talet och början på något nytt. I sin bok Världspolitiken 1911-1919 skriver 1920 geopolitikens fader, statsvetaren Rudolf Kjellén, om utbrottet av världskriget, slutet på ett långt 1800-tal:

\begin{abstract}
Skottet i Sarajevo, som ett skott i fjällen, framkallade lavinen, därför att spänningen redan förut stigit till yttersta gränsen av det uthärdliga. Stora krafter, långt ovanför enskilda huvuden, hade framkallat spänningen. Så till vida frestas man till det ordet, att alla och ingen bära skulden. (Kjellén, 1920, s. 121)
\end{abstract}

För många framstår Günter Schabowskys oklara förmodan i Östberlin den 9 november som startskottet för slutet på det korta 1900-talet med dess världskrig och kalla krig. Men liksom i Kjelléns metafor är det de geopolitiska spänningarna - i vid mening och på alla nivåer - och deras tillfälliga upplösningar som leder till en oförutsedd och oförutsägbar genomgripande förändring av Europa.

Ett kalenderår är för en geopolitisk process inget absolut utsnitt ur historien. Orsakerna till händelser och handlingar ligger i olika tider och rum, och så gör deras effekter. Men med utgångspunkt från ett "märkesår», snarare ett märkligt år, har den norske journalisten Per Anders Madsen skrivit en bok som i närbild skildrar händelser och handlingar på platser i Europa där nya geopolitiska väderlägen skapades ibland över en natt.

Per Anders Madsen är givetvis klar över att just kalenderåret 1989 inte ger svar på frågorna om den stora förändringen, kalla krigets slut, men under ett mycket kort tidsspann utspelar sig händelser som var för sig kan synas obetydliga men som efteråt ger en förklaring till att utfallet blev ett annat än 1914. Upptakten i boken är en aktion i Leipzig i januari, en aktion som liknar handlingen från nazitiden i Hans Falladas verklighetsbaserade Ensam $i$ Berlin men som går snett nästan från början. Misslyckandet blir inledning till en process som på avstånd från händelsernas maktcentrum ändock skall visa sig viktig, kanske avgörande, för slutresultatet.

Upplägget är ett antal kapitel i ungefärlig tidsordning från vinter till höst, ofta inlett med en handling och några namngivna aktörer, och med en beskrivning av 
förutsättningarna, ofta längre bak i tiden. Scenen skiftar mellan Leipzig och geopolitikens storstäder: Berlin, Moskva, Warszawa och Washington. Utvecklingen pendlar mellan hopp och förtvivlan.

Madsen skriver föredömligt: "Jeg er formidler, ikke forsker, og har gjort bruk av en elemæntar journalistisk arbeidsmetode: dra ut og snakke med folk» (s. 346). Men boken bygger också, vilket Madsen framhåller, på läsning av ett antal verk om tiden, inte minst biografier. Både bibliografin och hänvisningarna är av god kvalitet, men det kan ibland vara oklart vad i en lång framställning som hänförs till samma referens.

Boken har sitt fokus på Leipzig. Det finns förklaringar: staden blev centrum för det fredliga upproret mot DDR-regimen. Det kan bero på enskilda människor, vilka Madsen skildrar från egna möten och andrahandskällor. Men dessa människor kunde agera i ett civilt samhälle som var mindre hårt bevakat av Stasi än Östberlin, och med en lång tradition av opposition ända från den lutherska reformationen. Miljöproblemen, kommunistregimernas oskyddade akilleshäl, bidrog till en uppdämd ilska. Stadens topografiska struktur, illustrerad av en karta på omslagets insida med angivelse av de viktigaste händelsernas lokalisering, skapade en naturlig samlingsplats för mötena. Övriga orter och deras aktörer får mindre plats och är i större utsträckning baserade på andrahandskällor. Detta kan betraktas som en svaghet, men det är snarare boktiteln som kan leda fel. Leipzig är bokens huvudstad, men några av aktörerna där har goda kontakter med Prag och framförallt med Polen, med de rotlösa varvsarbetarna i Gdańsk och Szczecin, i sin tur styrkta av den katolska kyrkan, som kom att spela en frigörande roll liknande den som vissa lutheranska präster utförde hemma i DDR. Det gällde inte bara i Leipzig, kyrkan kom att spela en roll som samlingspunkt för dissidenter även $i$ andra delar av staten, vilket exempelvis framgår av Joachim Gaucks memoarer, som Madsen inte tar upp.

Bokens upplägg skapar en spänning, nästan som en "krimi», trots att utgången är given. Eller är den det? I ett Etterspill redogör Madsen för den komplicerade och långtifrån rätlinjiga process som ledde till Staten som forsvant, inte minst det intrikata spelet mellan tre individer, Michael Gorbatjov, George H. W. Bush och Helmuth Kohl och deras rådgivare och opponenter. Vid ett återbesök i Leipzig 2018 kan Madsen konstatera att freden räddades och Tyskland återförenades, men att Leipzigbornas förhoppningar 1989 bara delvis förverkligats. 